\title{
Arti Penting Merk dan Pengelolaannya
}

\author{
Oleh : Asmai Ishak
}

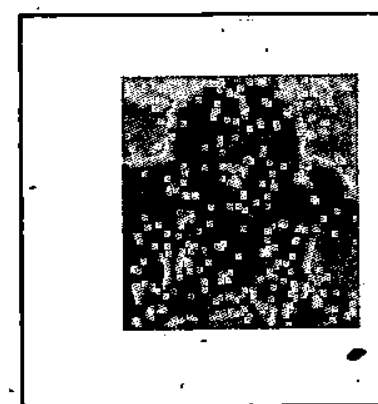

Pendahuluan

Pada awalnya, barang dan jasa dipasarkan tanpa merk. Produsen dan perantara menjual produknya langsung kepada konsumen tanpa memasang identitas apapun. Sebaliknya, saat ini, hampir semua produk dipasarkan dengan menggunakan merk, baik merk produsen/ pembuat produk atau merk penyalumya.

Produsen lebih suka memberi merk -produk yang dipasarkannya mengingat pemberian merk suatu produk tidak hanya meliputi masalah pengepakan, pemberian label, tetapi juga menyangkut jaminan bahwa produk akan memuaskankebutuhan konsumen. Seperti yang diungkapkan oleh Kotler (1994) bahwa pemberian merk pada suatu produk dapat memberikan beberapa keuntungan bagi penjual/pembuatnya, antara lain :

- merk dapat mempermudah para penjual dalam memproses pesanan dan menangani permasalahan yang nuuncul. - merk memberikan perlindungan formal bagi penjual/pembuat dari usaha pcmbajakan/penjiplakan yang dilakukan pihak lain.

- merk dapat memberikan kesempatan bagi penjual untuk menarik konsumen yang loyal dan menguntungkan.

- merk dapat mempermudah pensegmentasian pasar sasaran

- merk yang baik dapat membangun citra perusahaan

Dilain sisi, distributor menggunakan: suatu merk sebagai alat untuk mempermudah penanganan produk tersebut, pengidentifikasian pemasoknya, dan mempertahankan standar kualitas serta meningkatkan tingkat kesukaan konsumen. Sementara, bagi konsumen, adanya merk suatu produk dapat mempermudah mereka dalam mengidentifikasi perbedaàn kualitas produk sejenis dan berbelanja secara efisien.

Berdasarkan kenyataan-kenyataan diatas nampak bahwa merk suatu produk memiliki,peranan yang sangat penting baik bagi produsen, distributor, maupun bagi konsumen.

Proses Pengambilan Keputusan Konsumen

Banyak perusahaan - besar menggunakan konsep pemasaran untuk mempertahankàn tingkat pertumbuhan, terutama pada tingkat perekonomian yang 
semakin menurun. Dengan menggunakan konseppemasaran, perusahaanmemandang para pelanggannya sebagai suatu asset yang sangat berharga, yang mereka peroleh dengan memuaskan kebutuhan mereka lebih baikdaripada parapesaing(Oxenfeldt \& Moore, 1978). Pemikiran yang berorientasi pada konsumen seperti ini - mengharuskan perusahaan untuk mengidentifikasi kebutuhan konsumen secara akurat dan mengetahui tentang proses pembuatan keputusan pembelian para konsumennya. Dengan memahami faktorfaktor tersebut, perusahaan dapat mempengaruhi proses pengambilàn keputusan konsumennya melalui kebijakan bauran pemasarannya, khususnya kebijak promosi, sehingga konsumen tersebut bersikap positif terhadap produk atau merk perusahaan.

Proses pengambilan keputusan pembelian dari seorang konsumen dimulai pada saat munculnya kebutuhan yang kemudian diikuti oleh pencarian informasi, evaluasi dan seleksi, pemilihan toko dan pelaksanaan pembelian, dan diakhiri oleh evaluasi pasca pembelian. Ada berbagai macam tipe proses pengambilan keputusan. konsumen, mulai dari tipe keputusan yang tidak terlalu melibatkan konsumen sampai pada tipe keputusan yang melibatkan konsumen secara aktif. Dengan mempertimbangkan tingkat keterlibatan konsumen dalam pembelian, Hawkins, Best, \& Coney (1992) mengklasifikasikan proses pembuatan keputusan konsumen menjadi tiga macam yaitu proses pembuatan keputusan kebiasaan (habitual), terbatas (limited), dan luas (extended).

Pada pembuatan keputusan yang berdasarkan kebiasaan tingkat keterlibatan konsumen dalam pembelian sangat rendah dan keputusan atau pembelian yang. dilakukan merupakan suatu pengulangan. Sehingga dalam tipe keputusan ini, konsumen tidak melakukan pencarian informasi di luar dirinya, mengingat dalam memorinya sudah tersedia informasitentang produk atau merk yang disukai dan dianggap dapat memenuhi kebutuhan yang muncul. Tingkat keterlibatan konsumen sedikit meningkat pada tipe keputusan terbatas. Pada tipe inị konsumien sedikit melakukan pencarian informasi di luar dirinya, dan mengevaluasi beberapa alternatif produk atau merk untuk memenuhi kebutuhannya. Sebaliknya, dalam pengambilan keputusan yang luas tingkat keterlibatan konsumen relatif tinggi.Pencarian informasi dilakukan baik internal maupun external secara luas, dan kemudian diikuti dengan evaluasi yang cukup rumit atas altematif-altematif yang muncul. Sesudah pembelian dilakukan biasanya masih diikuti oleh suatu evaluasi pasca pembelian sebagai akibat dari munculnya keraguan atas kebenaran keputusan yang telah dibuatnya. Namun demikian, perlu disadari. bahwa pengaplikasian tipe keputusan yang terakhir -ini sangat terbatas.

Pada umumnya, konsumen cenderung melakukan evaluasi berdasarkan atribut produk di awal proses dan evaluasi berdasarkan merk pada fase berikutnya. Seperti yang disimpulkan oleh Jacoby (1974/1975), bahwakonsumen hanya dapat menggunakan informasi yang terbatas secara efektif.Mereka sering menggunakan merkdan informasi harga dalam pembuatan keputusannya. Ketika telah tersedia sebuah merk, mereka cenderung tidak mencari informasi lain. Ini menunjukkan bahwa 
merk tersebut dipakai sebagai informasi yang valid dalam keputusan yang mereka buat. Simplifikasi proses pembuatan keputusan seperti ini mengarah pada apa yang dikenal sebagai brand loyalty.

Studi yang dilakukan oleh Spence dan Engel (1970) menunjukkan bahwa brand loyaltydapatmempengaruhi persepsi seseorang. Brand loyalty dapat terjadi baik pada barang tahan lama maupun barang tidak tahan lama (durable and noindurable goods). Allison dan Uhl (1970) mendukung hasil studi tersebut: Mereka menyimpulkan bahwa perbedaan produk, dalam pikiran konsumen, muncul utamanya melalui persepsi mereka karena usaha-usaha pemsaran seperti merk, label, dan sejenisnya bukan karena perbedaan fisik produk yang mereka ketahui.. Namun demikian, masih ada silang pendapat tentang brand loyalty. pada barang tahan lama. Newman dan Staclin (1973), yang mendukung bahwa sikap pada barang tahan lama dapat memprediksi pilihan konsumen berikutnya, membuktikan bahwa sejumlah konsumien yang substansial, secara sadar atau tidak, meminimalkan pencarian informasi dengan membatasi perhatian mercka pada merk yang. sudah mereka kenal, dan memilih produk harganya wajar. Dalam kasus ini konsumen menggunakan merk sebagai alat untuk mengurangi resiko dan mengatasi pemilihan produk yang cukup rumit dan sulit pengevaluasiannya.

Di lain pihak, Day dan Deutscher (1982) berpendapat bahwa sikap pada barang tahan lama merupakan prediktor yang lemah bagi pilihan konsumen bcrikutnya. Lebih lanjut, mereka menyebutkan bahwa tidak ada hubungan khusus antara situasi atau kebutuhan seseorang saat ini dengan produk atau merk yang sedang dicari. Ketika pencarian informasi yang serius dilakukan karena kebutuhan untuk penggantian produk atau adanya perubahan kebutuhan dalam keluarga, kebutuhan seseorang menjadi menonjol dan informasi dicari dan dievaluasi secarakritis. Pada fase ini, hampir 'semua konsumen akan terbuka untuk informasi baru yang pada akhimya akan merubah atau membentuk sikap mereka yang baru.

Akhimya, Ray (1982) menegaskan bahwa perusahaan dapat mempertahankan brand loyalty dengan mempertahankan sejumlah advertensi dengan asumsi kualitas produk tetap dipertahankan dan produk tersebut tidak ketinggalan zaman.

\section{Arti Pentingnya Merk Bagi Perusahaan.}

Seperti yang disebutkan didepan, scbuah keuntungan yang akan diperoleh perusahaan dari pemberian merk atas produk yang dihasilkannya, adalah adanya kesempatanuntuk menarik konsumen yang loyal dan menguntungkan. Perusahaan perintis (Pioneering firm), yaitu perusahaan yang masuk pertama kali ke pasar, sangat dimungkinkan memperoleh keuntungan tersebut. Beberapa peneliti menemukan hubungan yang kuat antara urutan masuk ke pasardan pangsa pasar, khususnya dalam barang konsumsi. Hubungan ini diduga berasal dari keuntungan informasi konsumen.

Selanjutnya Schmalensee (1982) menunjukkan bahwa perilaku konsumenyang rasional, dalam menghadapi informasi yang kurang lengkap tentang kualitas produk, dapat mendatangkan keuntungan yang cukup lama bagi perusahaan perintis. 
Dalam hal ini, proses bclajar konsumen, berdasarkan pengalaman pemakaian, memberikan keuntungan informasi bagi perusahaạn perintis dari pada pesaingnya. Dalam kontek pemasaran, keuntungan ini akan mengarah pada peningkatản kesadaran (awarèness) merk yang lebih besar bagi merk perintis dan dimasukkannya merk terebut dalain evoked set (kumpulan merk yang dijadikan alternatif "pemuas kebutuhan) konsumen. Berdasarkan fenomena tersebut, perusahaan printis dapat mempertahankan merknya sebagai pemimpin pasar dalam jangka waktu yang relatif lama. Coca Cola, Kodak, Good Year adalah contoh perusahaan perintis yang masih tetap sebagai pemimpin pasar sejak tahun 1920-an.

Namun demikian, Schamalensee mengungkapkan bahwa kekuatan dari keuntungan informasi bagi perusahaan. perintis tergantung pada tipe industrinya. Keuntungan informasi ini akan lebih besar dampaknya pada produk yang härga dan frekwensi pembeliannya rendah. Untuk produk yang harganya tinggi, konsumen akan cenderung mencari dan menggunakan banyak sumber informasi, sehingga keuntungan produk/perusahaan , perintis akan menurun. Sementara rendahnya frekwensi pembelian akan menguntungkan produk/perusahaan perintis dalam hal meminimalkan terjadinyakonsumen pindah pada merk lain (brand switching). Robinson dản Fomell (1985) menambahkan bahwa kekuatan dari keuntungan informasi pada konsumen tersebut juga dapat bervariasi berdasarkan pada stabilitas karakteristik produk. Dalam industri yang karakteristik produknya stabil, konsumen mungkin hanya mengandalkan informasi dari pembelian scbelumnya. Tetapi untuk produk yáng karakteristiknya sering berubah konsumen cenderung untuk mencari tambahan informasi lain, selain informasi dari pengalaman pembelian sebelumnya. Dengan demikian, keuntungan informasi sebagai produk/perusaháan perintis mungkin akan berkurang ketika tingkat perubahan produk dalam industri meningkat.

Lebih lanjut Robinson dan Fomell mengungkapkan bahwa-industri yang perbandingan biaya advertensi dengan penjualannya cukup tinggi mempunyai hambatan memasuki pasar yang substansial dan dengan sendirinya perusahaan printis dapat mempertahankan posisinya. Hal ini sebagai akibat dari pengalaman pembelian dan akumulasi dari pesan-pesan advertensi produk perintis yang dialami konsumen. Sehingga produk yang memasuki pasar belakangan, yang nota benenya frekwensi pembeliannya oleh konsumen masih terbatas, akan'mengalami kesulitan untuk menyampaikan pesan-pesan advertensinya dan mempengaruhi perilaku pembelian target konsumennya.

Lebih dari pada itu, ada keuntungan. lain yang bisa diperoleh produk perintis yang merknya sudah dikenal baik (wellknown) di pasar. Di tahun 1980 an, banyak perusahaan yang menemukan bahwa brand leverage merupakan salah satu alat yang paling baik dälain strategi pemasaran. Seperti yang diungkapkan oleh Stem (1986) bahwa sebuah merk yang terkenal dapat memperkecil resiko kegagalan penjualan produk baru, atau bahkan dapat mensukseskan penawaran produk baru, khususnya produk paket. Pendapat inilebih ditegaskan oleh Park, Jaworski, dan 
MacInnis (1986) yang mengatakan bahwa ada keuntungan bawaan (built in advantage) ketika merk dan citra sudah dikenal baik, karena produk/merk tersebut dapat langsung memenuhi apa yang diinginkan konsumen: Selanjutnya, Stern berpendapat bahwa brand leverage dapat beresiko bagi perusahaan yang hanya menghasilkan satu macam produk, karena kegagalan dapat memberikan aib pada citra perusahaan secara keseluruhan. Hal ini pemah dialami oleh Perusahaan General Motors ketika gagal dalam menawarkan Cadillac Cimaron beberapa tahun yang lalu. Akibatnya, perusahaan tersebut hari smengeluarkan tambahan biaya yang relatif besar untuk membangun kembali citranya sebagai pemimpin pasar di industri mobil. Untúk menghindari bahaya potensial dari brand leverage ini, banyak perusahaan melakukan riset pasar yang menyeluruh sebelumnya, seperti meneliti persepsi konsumen tentang kesesuaian merk dengan produk baru yang akan dipasarkan. Cara lain untuk mengatasi bahaya potensial tersebut adalah dengan melakukan semileveraging brand name.

\section{Pengelolaan Citra Baik Sebuah Merk.}

Citra (image) merupakan suatu persepsi yang diciptakan oleh perusahaan. Citra merk (brand image) tidak hanya merupakan suatu fenomena persepsi yang bisa dipengaruhi oleh aktifitas komunikasi perusahaan saja. Citra merk merupakan pemahaman konsumen yang diderifasi dari seluruh kegiatan yang berkaitan dengan merk yang dilakukan oleh perusahaan.

Park dkk mengemukakan bahwa. faktor penting yang berpengaruh dalam pemilihan sebuah konsep merk adalah kebutuhan konsumen baik fungssional, simbolik, atau pengalaman kebutuhannya. Banyak merk menawarkan dari kombinasi dari manfaat fungsional, simbolik, dan pengalaman. Oleh karenanya sangat dimungkinkan untuk mengembangkan citra. merk ini dengan menggunakan dua konsep atau lebih. Lebih lanjut Park dkk mengungkapkan bahwa pengelolaan citra umum (generic image) mungkin sulit, mengingat :

- konsep yang berbeda membutuhkan penggunaan strategi penempatan produk jangka panjang yang berbeda.

- sebuah merk dengan konsep ganda akan bersaing dẹngan sejumlah mérk yảng lebih banyak.

- sebuah merk dengan konsep ganda mungkin kurang efektif dalam membentuk sebuah citra/posisi karena menyulitkan 'konsumen untuk . mengidentifikasi arti dasar merk yang bersangkutan.

Terlepas dari kebutuhan umum konsumen, pemilihan sebuah konsep juga didasarkan pada kesesuaiannya dengan kecenderungan lingkungan makro dan lingkungan mikronya. Lingkunganintemal perusahaan juga harus dipertimbangkan. Pada saat sebuah konsep berdasarkan kebutuhan yang luas sudah dipilih, hal ini bisa dipergunakan sebagai pedoman dalam keputusan penempatan produk, dan karenanya menentukan kelompok perusahaan pesaing. Selanjutnya, hubungần antara konsep merk dan citranya harus dikelola sepanjang daur hidup merk tersebut. Park dkk mengajukan tiga tahap konsep pengelolaàn merk : tahap pendahuluan, pengembangan, dan pertahanan. 
1. Tahap Pendahuluan

Tahap ini dimulai dengan pelaksanaan beberapa kegiatan yang. ditujukan untuk membeniuk citra/posisi merk selama masa perkenalan di pasar. Bauran pemasaran mclaksanakan dua tugas yang saling berkaitan yang mempengaruhi citra/posisi merk, yaitu pengkomunikasian citra merk dan tugas operasi (operating tasks). Apabila elemen-elemen bauran pemasaran konsisten dan terkoordinasi dengan kedua tugas terscbut, maka terjadinya sinergi dalam bauran pemasaran. sangat dimungkinkan.' Tujuan lain dari pengelolaan konsep nicrk dalam tahap ini adalah untukmembangun sebuah cil ra yang dapat diperluas dengan mudah dan logis pada tahap berikutnya.

\section{Tahap Pengembangan}

Pada tahap ini, strategi penempatan produk difokuskan pada memperkuat nilai dari merk sehingga anggapanlebih superior dari merk pesaing dapat dibentuk atau dipertahankan.; Strategi penempatan pada tahap ini mungkin membutuhkan perubahan dalam komponen bauran pemisaran. Seperti halnya pada tahap pendahuluan, clemienelemen bauran pemasaran pada tahap ini akan sangat efektif dan efisien dalam penambahan nilai dari citra jika konsisten dengan tujuankomunikasi danoperasi, serta saling melengkapi antara satu dengan lainnya.

\section{Tahap Pertahanan}

Tahap yang terakhir ini ditujukan untuk mengaịtkan citra merk yang telah dikembangkan dengan cilra, merk produk lain yang diproduksi perusahaan. Bcberapa produk, dengan citra yang sama, akan saling membanlu memperkuat citra merk satu dengan yang lain. Penguatạn citra merk dalam tahap ini bukan berarti bahwa tahap pengembangan merk, berhenti. Pengembangan merk terus dilakukan scpanjang daur hidup merk yang bersangkutan. Pada dasarnya, tahap pertahanan ini scbaiknya dikaitkan lebih dckat pada strategi pengelolaan lini produk dari pada pengelolaan konsep merk secara individual.

Tahap pertahanan dapat menjadi sangat penting karena alasan berikut :

- biaya komunikasi untuk masingmasing merk akan menurun karena merk dengan citra yang sama akan saling menguatkan satu dengan yang lain.

- citra yang sama dapat membantu terciptanya persepsi bahwa. produk komplemen scbaiknya dikonsumsi secara bersama-sama (paket)

- merk dengan citra yang sama dapat membantu untuk membawa citra perusahạan dan menunjukkan hubungan perusahiaan pada kebutuhan konsưmen secara luas.

\section{Ringkasan}

Sebuah merk produk memiliki suatu pcran yang penting baik bajgi konsumen maupun bagi pẹrusahaan. Konsumen menggunakan' merk untuk menudahkan proses pengambilan keputusan. Sementara perusahaan menggunakan merk untuk beberapa tujuan. Dua tujuan yang sangat penting bagi perusahaan adalah untuk membangun citra korporasi dan menarik konsumeniloyal dan sekelompok konsumen yang menguntungkan. Perusahaanperusahaan yang merk/produknya disukai konsumen, dapat menikmati keuntungan kompetitif, karena mereka akan menjadi 
pemimpin pasar dalam industrinya.

Pada umumnya, perusahaanperusahaan yang menjadi pemimpin pasar. adalah perusahaan yang masuk pertama kali ke pasar dan memperoleh keuntungan informasi konsumen. Keuntungan tersebut memungkinkan ' mereka untuk mempertahankan posisinya untuk jangka waktu, yang cukup lama, asalkan mereka dapat memainkan perannya dengan tepat. Tidak ada keraguan bahwa perusahaan barang tidak tahan lama (nondurable good) dapat mempertahankan posisinya sebagai -pemimpin, karena kestabilan dari karakteristik produk dan rendahnya harga jualnya. Sementara perusahaan produk. tahan lamà yáng karakteristik produknya tidak stabil dan harganya yang cukup Linggi, kecil kemungkinannya untuk dapat mempertahankan posisinya sebagai pemimpin pasar dalam kurun waktu yang lama.

Selanjutnya, perusahaan yang merknya sudah dikenal baik dapat menggunakan brand leverage dalam strategi pemesarannyä. Namundemikian', meskipun banyak perusahaan yang berhasil menggunakan strategi ini, stratcgi ini masih mengandung beberapa bahaya. Untuk menghindari bahaya-bahaya tersebut, perusahaan harus melakukan riset pasar yang komprehensif. Cara lain untuk meminimalkan bahaya ini adalah dengan melakukar' semi-leveraging brand name.

Akhimya, perusahaan seb́aiknya mengelola cifra merknya dengan tepat. Karena suatu citra merk mempunyai dampak langsung pada penjualan dan miengurangi dampak pada hubungan antara strategi daur hidup produk dan penjualan. Untuk mengelola citra merk, Pard dkk mengajukan tiga tahap konsep pengelolaan merk yaitu tahap pendahuluan, pengembangan, dan pertahanan.

\section{Daftar Pustaka}

Kotler,Philip (1994), "Marketing Management : Analysis, Planning, Implementation. and Control", Engelwood Cliffs, New Jersey, Prentice Hall Inc., Edisi Delapan.

Oxenfeldt, A.R. \& W.L. Moore (1978), "Customer or Competitor : Which Guideline for Marketing", Managemen. Review, 'Agustus, hal. 43-48.

Hawkin, D.I; R.J. Best \& K.A. Coney (1992), "Consumer Behavior : Implication for Marketing Strategy", Texas, Business Publication Inc., Edisi Lima.

Jacobi, J (1974), "Brand Choice Behavior as a Function of Information Load", Journal of Consumer Research, 1.

Spence, H.E. \& J.F. Engel (1970), "The Impact of Brand Preference on the Perception of Brand Name : A Laboratory Analysis", diungkap dalam Kollat, D.T; R.D. Blackwell, \& J.F. Engel, "Research in Consumer Behavior". Holt, Rinehartand Winsion Inc.; hal. 61-70.

Allison, R.J. \& K.P. Uhl (1970), "Influence of Beer Brand Identification on Tatste Perception" diungkap dalam Kollat dkk, hal. 71-78.

Newman, J.W. \& R. Staelin (1973), "Information Sources of Durable Goods", Journal of Advertising Research, April, hal. 19-29.

Day, G.S. \& T. Deutscher (1982), "Attitudinal Predictions of Choice of Major Appliance Brands, Journal of Marketing Research, XIX, May, hal. 192-198.

Ray, S.P. (1982), "The Effect of Advertising on High and Low Loyalty Consumer Segments", Journal of Consumer Research, 
9, hal. 77.

-Schamalensee, R. (1982), "Procuct Differentiation Advantages of Pionering Brand", American Economic Review, 27, hal. 305-327.

Robinson, W.T. \& C. Fornell, "Sources if Market Pioneèr Advantages in Consumer Goods Industries", Journal of Marketing Research, XXII, Agustus, hal.
305-327.

Stern, A.L. (1986), "New Payofffrom OldBrand Name", Annual Editions Marketing, hal. 145-147.

Park, C.W; BJ. Jaworski; \& D.J. MacInnis (1986), "Strategic Brand Concept Image Management",Journal of Marketing, 50, Oktober, hal. 135-145. 